\title{
Dietary Hog Plum (Spondias pinnata (L.f) Kurz) Could Modulate Fermentation Process, and Feed Digestibility, As Well As and Reduce Protozoal Population: In Vitro Study"
}

\section{Anusorn Cherdthong*, Nareerut Unnawong, Benjamad Khonkhaeng, Rittikeard Prachumchai}

Tropical Feed Resources Research and Development Center (TROFREC), Department of Animal Science, Faculty of Agriculture, Khon Kaen University, Khon Kaen 40002, Thailand

\begin{abstract}
The research was to elucidate the influences of dietary hog plum supplementation on nutrient digestibility, fermentation characteristics, protozoal population and kinetics of gas production. Completely randomized design $(\mathrm{CRD})$ was used and the treatments were 6 levels of hog plum supplementation at 0, 0.5, 1.0, 1.5, 2.0 and $2.5 \mathrm{mg}$ DM. Hog plum consisted of CP at 5.6\% DM and saponins was found about 9.4\%. Supplementation of hog plum did not alter gas production from the soluble fractions $(a)$, gas production from the insoluble fraction $(b)$ and the potential extent of gas production $(a+b)$ and gas production rate constants for the insoluble fraction $(c)(\mathrm{P}>0.05)$. Furthermore, cumulative gas production from $96 \mathrm{~h}$ of incubation did not changed by hog plum complementation and were ranged from 154.7 to $158.8 \mathrm{ml} / 0.5 \mathrm{~g}$ DM. Ruminal $\mathrm{pH}$ of $2 \mathrm{~h}, 4 \mathrm{~h}$ after incubation and average $\mathrm{pH}$ were not significantly different among various doses of hog plum complementation $(\mathrm{P}>0.05)$. Average $\mathrm{NH}_{3}-\mathrm{N}$ concentration were highest increased when hog plum supplementation at 2.0 to $2.5 \mathrm{mg}$ and increased by 16.4 to $17.5 \%$, respectively compared to no supplemented group. At $2 \mathrm{~h}$ after incubation, there were no changed on protozoal counts $(\mathrm{P}>0.05)$, whereas the reduction of protozoal counts were found when added hog plum at $4 \mathrm{~h}$ after incubation $(\mathrm{P}<0.05)$. In addition, mean concentration of protozoa was reduced when increasing doses of added hog plum $(\mathrm{P}<0.05)$. Supplementation of hog plum at 2.0 to $2.5 \mathrm{mg}$ could reduce protozoal population by $71.2 \%$ when compared to no supplemented group. Supplementation of hog plum did not alter IVDMD and IVOMD and were average ranged from 57.1 to $58.5 \%$ $\mathrm{DM}$ and 62.4 to $64.1 \% \mathrm{DM}$, respectively $(\mathrm{P}>0.05)$. It could be summarized that supplementation hog plum did not adversary affect ruminal fermentation, kinetic of gas and in vitro digestibility, whereas population of protozoa was decreased when supplementation hog plum up to $2.0 \mathrm{mg}$.
\end{abstract}

Keywords | Tropical plant, Greenhouse gas, Saponin, Methane, Protozoa

\footnotetext{
Received | July 01, 2019; Accepted | September 10, 2019; Published | November 15, 2019

*Correspondence | Anusorn Cherdthong, Tropical Feed Resources Research and Development Center (TROFREC), Department of Animal Science, Faculty of Agriculture, Khon Kaen University, Khon Kaen 40002, Thailand; Email: anusornc@kku.ac.th

Citation | Cherdthong A, Unnawong N, Khonkhaeng B, Prachumchai R (2019). Dietary Hog Plum (Spondias pinnata (L.f) Kurz) Could Modulate Fermentation Process, and Feed Digestibility, As Well As and Reduce Protozoal Population: In Vitro Study”. Adv. Anim. Vet. Sci. 7(12): 1054-1059.

DOI | http://dx.doi.org/10.17582/journal.aavs/2019/7.12.1054.1059

ISSN (Online) | 2307-8316; ISSN (Print) | 2309-3331
}

Copyright (C) 2019 Cherdthong et al. This is an open access article distributed under the Creative Commons Attribution License, which permits unrestricted use, distribution, and reproduction in any medium, provided the original work is properly cited.

\section{INTRODUCTION}

$\mathrm{T}$ he manipulation of ruminal fermentation was elucidate used to optimize rumen fermentation for enhancing feed use, animal production and reducing enteric methane $\left(\mathrm{CH}_{4}\right)$ emission (Hristov et al., 2013; Cherdthong et al., 2019). Johnson and Johnson (1995) noted that the $\mathrm{CH}_{4}$ produced is not utilized by the ruminant itself, but instead represents an energy loss of $2-12 \%$ of gross energy. Accordingly, ruminal protozoa were removed by defaunation to reduce $\mathrm{CH}_{4}$ emission in the rumen and enhance the protein outflow in the small intestine, indicating in the enhanced nutrient use and performance production of the ruminants (Santra and Karim, 2003). Some elimination options such as chemical inhibitors, and ionophores inhibit rumen protozoa. 
However, consistent influences have not been verified for practical use (Hristov et al., 2013; Cieślak et al., 2016). Moreover, there is increasing interest in studying tropical plants as supplemental feed to reduce chemical inhibitors in animal nutrition.

Tropical plants consist of high contents of saponins which have become noticeable choices for prohibiting protozoa in the rumen (Gunun et al., 2019). These possibly be that these compounds may disturb the activity of ruminal protozoa, likely by attaching the proteins and enzymes of the protozoal membranes (Hristov et al., 2013). Numerous reports demonstrated that the adding condensed tannins sources such as Terminalia chebula Retz or the Delonix regia seed could reduce the ruminal concentration of protozoa by $60 \%$ to $70 \%$ (Anantasook et al., 2016; Supapong et al., 2017; Cherdtong et al., 2019).

Hog plum (Spondias pinnata (L.f) Kurz) is a tropical native plant to India, Myanmar, Indonesia, Southern China, and throughout Thailand (Florido and Cortiguerra, 2003).Fruits are borne in terminal clusters of 10-15 fruits (Campbell and Sauls, 1994). The fruit is ovoid, $45 \mathrm{~cm}$ in length, color is yellow in color, and fleshy, with the drupe having a finely edible pulp. It contains many chemical compounds which that are important for pharmacological activities. Chalise et al. (2010) reviewed that the concentration of saponins in hog plum was $8.14 \mathrm{mg} / 100 \mathrm{~g}$ and therefore, it was hypothesized that hog plum could modify ruminal fermentation and reduce the protozoal population.

Thus, the research was to elucidate the influences of dietary hog plum doses on nutrient digestibility, fermentation characteristics, the protozoal population and the kinetics of gas production.

\section{MATERIALS AND METHODS}

\section{Hog Plum Preparation}

Hog plum fruits were collected during August, 2017 to January 2018, in Khon Kaen province, Thailand. The fruit were moved out of seeds and collected the peel for the test. The peel were oven dried at $60{ }^{\circ} \mathrm{C}$ for 24 hour, then was grounded to pass a 1-mm sieve and kept until test.

\section{Experimental Design And Treatments}

Completely randomized design (CRD) was used and the treatments were 6 levels of hog plum supplementation at 0 , $0.5,1.0,1.5,2.0$ and $2.5 \mathrm{mg} \mathrm{DM}$ with $0.5 \mathrm{~g}$ of substrates (60\% roughage and $40 \%$ concentrate) (see Table 1 ).

\section{RUMinAL INOCULA}

All processes between the ruminal fluid moving and inoculum periods were anaerobic techniques and sterile.
Two male dairy steer with an initial body weight of $400 \pm 20$ $\mathrm{kg}$ were used as rumen fluid donors. Ruminal fluid samples were obtained from animals before feeding in the morning, then was filtered through four layers of cheesecloth into prewarmed thermos flasks before moved to the in vitro laboratory.

Table 1: Feed formulation and chemical composition of diets.

\begin{tabular}{|c|c|c|c|}
\hline Item & Concentrate & Rice straw & Hog plum \\
\hline \multicolumn{4}{|l|}{ Ingredients, $\mathrm{kg} \mathrm{DM}$} \\
\hline Cassava chip & 55.0 & & \\
\hline Rice bran & 11.0 & & \\
\hline Coconut meal & 12.9 & & \\
\hline Palm kernel meal & 13.5 & & \\
\hline Urea & 2.6 & & \\
\hline Pure sulfur & 1.0 & & \\
\hline Mineral premix* & 1.0 & & \\
\hline Molasses, liquid & 2.0 & & \\
\hline Salt & 1.0 & & \\
\hline \multicolumn{4}{|c|}{ Chemical composition } \\
\hline Dry matter $(\%)$ & 91.3 & 93.3 & 87.6 \\
\hline \multicolumn{4}{|l|}{$\%$ of DM } \\
\hline Organic matter & 87.1 & 85.3 & 88.7 \\
\hline Ash & 12.9 & 14.7 & 11.3 \\
\hline Crude protein & 13.6 & 2.6 & 5.6 \\
\hline Neutral detergent fiber & 10.8 & 19.7 & 56.8 \\
\hline Acid detergent fiber & 6.9 & 11.3 & 36.3 \\
\hline $\begin{array}{l}\text { Saponins, mg/ } 100 \mathrm{~g} \\
\text { DM }\end{array}$ & - & - & 9.4 \\
\hline \multicolumn{4}{|c|}{$\begin{array}{l}\text { *Minerals and vitamins (each } \mathrm{kg} \text { contains): Vitamin } \\
\text { A: 10,000,000 IU; Vitamin E: 70,000 IU; Vitamin D: } \\
\text { 1,600,000 IU; Fe: } 50 \text { g; Zn: } 40 \text { g; Mn: } 40 \text { g; Co: } 0.1 \text { g; Cu: } \\
10 \text { g; Se: } 0.1 \text { g; I: } 0.5 \text { g. }\end{array}$} \\
\hline
\end{tabular}

The $0.5 \mathrm{~g}$ of substrate was obtained from $60 \%$ of roughage and $40 \%$ of concentrate. Substrates were milled to a 1- $\mathrm{mm}$ screen and weighed to $0.5 \mathrm{~g}$ of DM into $50 \mathrm{~mL}$ bottles for $96 \mathrm{~h}$. Media solution was performed as following to the method of Menke and Steingass (1988). All bottles with the mixture of substrate treatments were prepared in a water bath at $39^{\circ} \mathrm{C}$ for $1 \mathrm{~h}$ before filling with $40 \mathrm{~mL}$ of the artificial saliva solution.

\section{Fermentation Characteristics Determination}

The production of gas was collected at $0,1,2,4,6,8$, $10,12,18,24,48,72$ and $96 \mathrm{~h}$ and was calculated to the equation of Ørskov and McDonald (1979). The rumen solution mixture was sampled at $0,4,8,12$ and $24 \mathrm{~h}$ after inoculation. Rumen fluid inocula were then filtered through four layers of cheesecloth. Samples were used 
for ruminal $\mathrm{pH}$ determination using Hanna Instruments' HI 8424 microcomputer (Kallang Way, Singapore) and nitrogen $\left(\mathrm{NH}_{3}-\mathrm{N}\right)(\mathrm{AOAC}, 1998)$. The protozoal count was determined at 2 and $4 \mathrm{~h}$ of incubation using the direct counting microscopic $(150 \times)$ method based on the use of a haemocytometer (Boeco, Hamburg, Germany). In vitro DM digestibility (IVDMD) and in vitro organic matter digestibility (IVOMD) were elucidated after dissolving at 12 and $24 \mathrm{~h}$ after inoculum according to the method of Tilley and Terry (1963).

\section{Chemical Composition Analysis}

Hog plum peel, roughage and concentrate were dried at $60^{\circ} \mathrm{C}$ for $48 \mathrm{~h}$, ground to pass through a $1-\mathrm{mm}$ sieve (Cyclotech Mill, Tecator, Hoganas, Sweden) and used for nutritional determination and the gas analysis. The diets were chemically evaluated for dry matter (DM), ash and crude protein $(\mathrm{CP})$, organic matter $(\mathrm{OM})$ and acid detergent fiber (ADF) (AOAC, 1998). The content of neutral detergent fiber (NDF) was determined by the method of Van Soest et al. (1991). Saponins were evaluated by method based on Wang and Fang (2004) using the modified vanillin-sulfuric acid. Ingredients and nutritional content of diets are demonstrated in Table 1.

\section{Statistical Assay}

All data from the experiment were statistically analyzed as a CRD using the GLM procedure of SAS (1998) (Version 6.0; SAS Inst. Inc. Cary, NC). Results are presented as mean values with the standard error of the means. Differences between dietary means were evaluated by Duncan's New Multiple Range Test with $\mathrm{P}<0.05$ level of significance. Orthogonal polynomial contrast was performed to determine their responses.

\section{RESULTS AND DISCUSSION}

\section{Nutritional Value Of Feed And Hog Plum}

Table 1 shows the ingredient and nutritional composition of feed and hog plum. The concentrate diet contains 13.6\% $\mathrm{DM}$ of $\mathrm{CP}$, which could be because of the additional urea $(2.6 \% \mathrm{DM})$ in the ration. A high level of NPN in the ratio might be synchronized with a fermentable carbohydrate source from the cassava chip which include makes up $55 \%$ of the concentrate diet. It might be support ruminal microbial protein production and improve ruminal ecosystem proficiency. Hog plum consisted of CP at 5.6\% of DM, which could be an additional protein source when incorporated into the rumen. Furthermore, a secondary compound in hog plum, namely saponins, was found to make up about $9.4 \%$ of DM, which was greater than those reported by Chalise et al. (2010; 8.14\%). It might possibly be that due the differences in numerous factors, such as age, soil fertility, and preparation process. Saponins content in hog plum was closely to that of other tropical plants, such as Terminalia chebula Retz (9.9\%; Anantasook et al., 2016) and the Delonix regia seed (12.3\%; Supapong et al., 2017). Thus, based on the content of saponins in hog plum, it might be potential possible to modulate rumen fermentation, with more elucidation being required.

\section{Kinetics Of Gas And Cumulative Gas}

Table 2 elucidates the effect of hog plum on gas kinetics and gas production after incubation at $96 \mathrm{~h}$. The supplementation of hog plum did not alter gas production from the soluble fractions $(a)$, gas production from the insoluble fraction $(b)$, and the potential extent of gas production $(a+b)$ and gas production rate constants for the insoluble fraction $(c)(\mathrm{P}>0.05)$. Kinetic gas "c" were ranged from 0.044 - to $0.048 \mathrm{ml} / 0.5 \mathrm{~g}$ of $\mathrm{DM}$, while whereas the value of "b" were ranged from 151.8 - to $155.3 \mathrm{ml} / 0.5 \mathrm{~g}$ of DM. Furthermore, cumulative gas production from $96 \mathrm{~h}$ of incubation did not changed due to hog plum complementation and were ranged from 154.7 to 158.8 $\mathrm{m} / / 0.5 \mathrm{~g}$ of DM. Thus, increasing doses of hog plum did not adversary affect the kinetics of gas and could be maintain a normal condition of ruminal fermentation, as well as the and digestion of feed. In contrast, some previous research work indicated that the inclusion of a high level of saponins could prohibit ruminal bacteria, resulting in the suppression of in vitro gas production (Makkar, 2003; Jouany and Morgavi, 2007; Cieślak et al., 2016).

Table 2: Effect of hog plum on gas kinetics and cumulative gas at $96 \mathrm{~h}$ after incubation.

\begin{tabular}{|c|c|c|c|c|c|}
\hline \multirow{2}{*}{$\begin{array}{l}\text { Hog plum } \\
\text { supplementa- } \\
\text { tion, mg DM }\end{array}$} & \multicolumn{5}{|c|}{ Kinetic of gas", ml/ $0.5 \mathrm{~g} \mathrm{DM}$} \\
\hline & a & b & c & $a+b$ & $\begin{array}{l}\text { Cumulative gas } \\
\text { production, ml } \\
\text { DM incubated }\end{array}$ \\
\hline 0 & -1.6 & 155.6 & 0.048 & 154.0 & 157.8 \\
\hline 0.5 & -1.0 & 155.1 & 0.047 & 154.0 & 158.0 \\
\hline 1.0 & -1.6 & 152.2 & 0.045 & 152.9 & 156.1 \\
\hline 1.5 & -1.9 & 155.4 & 0.045 & 154.4 & 157.6 \\
\hline 2.0 & -1.2 & 153.0 & 0.045 & 155.3 & 158.8 \\
\hline 2.5 & -1.1 & 152.0 & 0.044 & 151.8 & 154.7 \\
\hline SEM & 1.1 & 1.53 & 0.020 & 1.7 & 1.72 \\
\hline P-value & 0.66 & 0.93 & 0.10 & 0.99 & 0.98 \\
\hline \multicolumn{6}{|l|}{ Contrasts $^{\dagger}$} \\
\hline Linear & 0.11 & 0.15 & 0.33 & 0.52 & 0.44 \\
\hline Quadratic & 0.97 & 0.88 & 0.55 & 0.12 & 0.25 \\
\hline
\end{tabular}

$* a$ - gas production from immediately soluble fraction; $b-$ gas production from insoluble fraction; $c$ - gas production rate constant for insoluble fraction (b); $a+b-$ potential extent (omit gas); ${ }^{\dagger} \mathrm{L}$ : Linear; Q: Quadratic. 


\section{Ruminal Fermentation And Protozoal}

Population

The influence of hog plum inclusion on rumen $\mathrm{pH}$ and $\mathrm{NH}_{3}-\mathrm{N}$ concentrations at $2 \mathrm{~h}$ and $4 \mathrm{~h}$ after incubation is shown in Table 3 . The ruminal $\mathrm{pH}$ of $2 \mathrm{~h}$ and, $4 \mathrm{~h}$ after incubation and average $\mathrm{pH}$ were not significantly different among various doses of hog plum supplementation $(\mathrm{P}>0.05)$. Average $\mathrm{pH}$ were ranged from 6.8 to 6.9 which was suitable rage for rumen microbial activity in the rumen (Calabrò et al., 2005). Concentration of $\mathrm{NH}_{3}-\mathrm{N}$ at $2 \mathrm{~h}$ after incubation did not alter by hog plum level $(\mathrm{P}>0.05)$, whereas increasing hog plum levels were significantly increased $\mathrm{NH}_{3}-\mathrm{N}$ concentration at $4 \mathrm{~h}$ after incubation. Average $\mathrm{NH}_{3}-\mathrm{N}$ concentration were highest increased when hog plum supplementation at 2.0 to $2.5 \mathrm{mg}$ and increased by 16.4 to $17.5 \%$, respectively compared to no supplemented group. This could be due to additional of $\mathrm{CP}$ content from hog plum $(5.6 \% \mathrm{CP})$ may provide protein supply for $\mathrm{NH}_{3}-\mathrm{N}$ synthesis. However, optimum range of $\mathrm{NH}_{3}-\mathrm{N}$ concentration were found in present study which could be indicate suitable rumen ecology and potential breakdown of feed when hog plum supplementation (1120 mg\%; Cherdthong et al., 2019).

Table 3: Influence of hog plum supplementation on ruminal $\mathrm{pH}$, ammonia-nitrogen $\left(\mathrm{NH}_{3}-\mathrm{N}\right)$ concentration and ruminal protozoal population at $2 \mathrm{~h}$ and $4 \mathrm{~h}$ after incubation.

\begin{tabular}{|c|c|c|c|c|c|c|c|c|c|}
\hline \multirow[t]{2}{*}{ Item } & \multicolumn{6}{|c|}{$\begin{array}{l}\text { Hog plum supplementation, } \\
\text { mg DM }\end{array}$} & \multirow{2}{*}{$\begin{array}{l}P- \\
\text { value }\end{array}$} & \multicolumn{2}{|c|}{ Contrasts $^{*}$} \\
\hline & 0 & 0.5 & 1.0 & 1.5 & 2.0 & 2.5 & & L & Q \\
\hline \multicolumn{10}{|c|}{ Rumen parameters } \\
\hline \multicolumn{10}{|c|}{$\mathrm{pH}$} \\
\hline $2 \mathrm{~h}$ & 7.1 & 6.9 & 7.1 & 6.9 & 7.1 & 7.1 & 0.12 & 0.85 & 0.96 \\
\hline $4 \mathrm{~h}$ & 6.7 & 6.7 & 6.9 & 6.5 & 6.9 & 6.9 & 0.22 & 0.25 & 0.85 \\
\hline Mean & 6.9 & 6.8 & 6.9 & 6.8 & 6.8 & 6.8 & 0.45 & 0.87 & 0.18 \\
\hline \multicolumn{10}{|c|}{$\mathrm{NH}_{3}-\mathrm{N}, \mathrm{mg} \%$} \\
\hline $2 \mathrm{~h}$ & 11.2 & 12.1 & 11.5 & 12.6 & 12.1 & 12.5 & 0.35 & 0.05 & 0.87 \\
\hline $4 \mathrm{~h}$ & $14.1^{\mathrm{a}}$ & $15.4^{\mathrm{a}}$ & $14.9^{\mathrm{a}}$ & $16.8^{\mathrm{ab}}$ & $18.7^{\mathrm{b}}$ & $17.8^{\mathrm{b}}$ & 0.04 & 0.02 & 0.76 \\
\hline Mean & $12.7^{\mathrm{a}}$ & $13.8^{\mathrm{a}}$ & $13.2^{\mathrm{a}}$ & $14.7^{\mathrm{ab}}$ & $15.4^{\mathrm{b}}$ & $15.2^{\mathrm{b}}$ & 0.02 & 0.04 & 0.23 \\
\hline \multicolumn{10}{|c|}{ Ruminal protozoal population, $\mathrm{x} 10^{6} \mathrm{cell} / \mathrm{ml}$} \\
\hline $2 \mathrm{~h}$ & 8.9 & 9.5 & 8.6 & 8.9 & 8.1 & 7.8 & 0.22 & 0.52 & 0.74 \\
\hline $4 \mathrm{~h}$ & $8.9^{\mathrm{a}}$ & $7.8^{\mathrm{a}}$ & $6.5^{\mathrm{ab}}$ & $5.3^{\mathrm{b}}$ & $2.3^{\mathrm{c}}$ & $2.5^{\mathrm{c}}$ & 0.03 & 0.04 & 0.88 \\
\hline Mean & $8.9^{\mathrm{a}}$ & $8.7^{\mathrm{a}}$ & $7.6^{\mathrm{a}}$ & $7.1^{1 \mathrm{~b}}$ & $5.2^{\mathrm{b}}$ & $5.2^{\mathrm{b}}$ & 0.04 & 0.02 & 0.55 \\
\hline
\end{tabular}

Ruminal protozoal population at $2 \mathrm{~h}$ and $4 \mathrm{~h}$ after incubation with various doses of hog plum supplementation are shown in Table 3. Numerous tropical plants consisting great contents of saponins have become interesting choices for interrupting protozoa in the rumen (Gunun et al., 2019). At $2 \mathrm{~h}$ after incubation, there were no changed on protozoal counts $(\mathrm{P}>0.05)$, whereas the reduction of protozoal counts were found when added hog plum at $4 \mathrm{~h}$ after incubation $(\mathrm{P}<0.05)$. In addition, mean concentration of protozoa was reduced when increasing doses of added hog plum $(\mathrm{P}<0.05)$. Supplementation of hog plum at 2.0 to $2.5 \mathrm{mg}$ could reduce protozoal population by $71.2 \%$ when compared to no supplemented group. This could possibly be because saponins may disturb the activity of ruminal protozoa, likely by attaching the proteins and enzymes of the protozoal cells (Cieślak et al., 2016). Thus, lowering in rumen protozoa could be relate to reduce $\mathrm{CH}_{4}$ production. Previous report demonstrates that supplementation of saponins source from Delonix regia seed reduced protozoal counts by $58 \%$ to $68.3 \%$ (Supapong et al., 2017; Cherdtong et al., 2019). The results of this trial clearly demonstrate the possibility to use the tropical plant to manipulate rumen fermentation, which is very important for animal performances as well as for the environment (Hristov et al., 2013).

Table 4: Influence of hog plum supplementation on in vitro dry matter digestibility (IVDMD) and in vitro organic matter digestibility (IVOMD) at $12 \mathrm{~h}$ and $24 \mathrm{~h}$ after incubation.

\begin{tabular}{|c|c|c|c|c|c|c|c|c|c|}
\hline \multirow[t]{2}{*}{ Item } & \multicolumn{6}{|c|}{$\begin{array}{l}\text { Hog plum supplementation, mg } \\
\text { DM }\end{array}$} & \multirow[t]{2}{*}{$\begin{array}{l}P \text { - } \\
\text { value }\end{array}$} & \multicolumn{2}{|c|}{ Contrasts } \\
\hline & 0 & 0.5 & 1.0 & 1.5 & 2.0 & 2.5 & & $\mathrm{~L}$ & Q \\
\hline \multicolumn{10}{|c|}{ IVDMD, \%DM } \\
\hline $12 \mathrm{~h}$ & 55.2 & 54.6 & 54.8 & 56.4 & 55.2 & 55.4 & 0.22 & 0.26 & 0.39 \\
\hline $24 \mathrm{~h}$ & 58.9 & 59.5 & 59.8 & 60.6 & 60.5 & 59.7 & 0.25 & 0.35 & 0.11 \\
\hline Mean & 57.1 & 57.1 & 57.3 & 58.5 & 57.9 & 57.6 & 0.11 & 0.33 & 0.88 \\
\hline \multicolumn{10}{|c|}{ IVOMD, \%DM } \\
\hline $12 \mathrm{~h}$ & 60.1 & 61.2 & 60.6 & 61.3 & 61.1 & 62.3 & 0.77 & 0.45 & 0.36 \\
\hline $24 \mathrm{~h}$ & 64.6 & 65.1 & 65.8 & 66.8 & 65.5 & 64.1 & 0.85 & 0.87 & 0.78 \\
\hline Mean & 62.4 & 63.2 & 63.2 & 64.1 & 63.3 & 63.2 & 0.24 & 0.98 & 0.18 \\
\hline
\end{tabular}

\section{IN VITRo DigestiBILITY}

Table 4 are shown theinfluence of hogplum supplementation on in vitro dry matter digestibility (IVDMD) and in vitro organic matter digestibility (IVOMD) at $12 \mathrm{~h}$ and $24 \mathrm{~h}$ after incubation. Supplementation of hog plum did not alter IVDMD and IVOMD and were average ranged from 57.1 to $58.5 \% \mathrm{DM}$ and 62.4 to $64.1 \% \mathrm{DM}$, respectively $(\mathrm{P}>0.05)$. Thus, increasing doses of hog plum did not adversary effect on reduction of nutrient digestibility and maintain normal feed utilization. In contrast, Cherdtong et al. (2019) indicated that increasing the saponins source (Delonix regia seed) at $14 \mathrm{mg}$ could be depressed in vitro fiber digestibilities by $10.5 \%$ in vitro digestibilities when compare to $12 \mathrm{mg}$. This might possibly be because high 
saponins in Delonix regia seed might inhibitory ruminal fibrolytic bacterial numbers via interfere enzymes activity and action on cell membranes and metal ion deprivation (Patra et al., 2010). However, no negatively influences of hog plum on feed digestion in present study might be due to the lower content of saponin (9.4 vs 12.3\%) and lower dose supplementation (2.5 vs $16.7 \mathrm{mg}$ ) compared with the Delonix regia seed.

\section{CONCLUSION}

Based on the current study, it could be concluded that adding of hog plum did not adversary affect ruminal fermentation, the kinetics of gas, and in vitro digestibility. Moreover, the protozoa count was reduced hog plum was added up to $2.0 \mathrm{mg}$. However, the concerning the necessity of further researches to confirm the influence of hog plum supplementation directly measuring the methane production is needed to confirm the influence of hog plum supplementation.

\section{ACKNOWLEDGMENTS}

The authors would like to express their most sincere thanks to the Increase Production Efficiency and Meat Quality of Native Beef and Buffalo Research Group, Khon Kaen University (KKU) for providing financial support for the research and the use of the research facilities. This work were also supported by the Thailand Research Fund (TRF) though he Royal Golden Jubilee Ph. D. Scholarship Program (contact grant $\mathrm{PhD} / 0023 / 2558$ ) and TFRIRG5980010. In addition, Miss Nareerut Unnawong was received the grant from Research Fund for Supporting Lecturer to Admit High Potential Student to Study and Research on His Expert Program Year 2018.

\section{CONFLICT OF INTEREST}

Authors declare no conflicts of interest of the manuscript.

\section{AUTHORS' CONTRIBUTION}

All authors contributed substantially to this study and are in full agreement with the content of the manuscript.

\section{REFERENCES}

-Anantasook N, Wanapat M, Gunun P, Cherdthong A (2016). Reducing methane production by supplementation of Terminalia chebula RETZ. containing tannins and saponins. Anim. Sci.J. 87:783-790. https://doi.org/10.1111/ asj.12494

-AOAC (1998). Official Methods of Analysis. 2, 16th edn. AOAC, Arlington, VA.

- Calabrò S, Cutrignelli MI, Piccolo G, Bovera F, Zicarelli F,
Gazaneo MP, Infascelli F (2005). In vitro fermentation kinetics of fresh and dried silage. Anim. Feed Sci. Technol. 123-124:129-137. https://doi.org/10.1016/j. anifeedsci.2005.04.047

-Campbell CW, Sauls JW (1994). Spondias in Florida. Fact Sheet HS63, a series of the Horticultural Sciences Department, Florida Cooperative Extension Service, Inst. Food Agric. Sci., Univ. Florida. pp. 1-3.

- Chalise PY, Acharya K, Gurung N, Bhusal RP, Gurung R, Basnet NS, Basnet P (2010). Antioxidant activity and polyphenol content in edible wild fruits from Nepal. J. Sci. Food Agric. 61: 425-432. https://doi.org/10.3109/09637481003591590

-Cieślak A, Zmora P, Matkowski A, Nawrot-Hadzik I, PersKamczyc E, El-Sherbiny M, Bryszak M, Szumacher-Strabe M (2016). Tannins from Sanguisorba officinalis affect in vitro rumen methane production and fermentation. J. Anim. Plant Sci. 26:54-62.

- Cherdthong A, Prachumchai R, Wanapat M, Foiklang S, Chanjula P (2019). Effects of supplementation with royal poinciana seed meal (Delonix regia) on ruminal fermentation pattern, microbial protein synthesis, blood metabolites and mitigation of methane emissions in native Thai beef cattle. Animals. 9(9): 625. https://doi.org/10.3390/ani9090625

- Florido HB, Cortiguerra FF (2003). Indian Hog plum. In: Lesser Known Edible Tree Species. Res. Inf. Ser. Ecosyst. 15: 2-4.

- Gunun P, Gunun N, Khejornsart P, Ouppamong T, Cherdthong A, Wanapat M, Sirilaophaisan S, Yuangklang C, Polyorach S, Kenchaiwong W, Kang S (2019). Effects of Antidesma thwaitesianum Muell. Arg. pomace as a source of plant secondary compounds on digestibility, rumen environment, hematology and milk production in dairy cows. Anim. Sci.J. 90: 372-381. https://doi.org/10.1111/asj.13147

-Johnson KA, Johnson DE (1995). Methane emissions from cattle. J. Anim. Sci. 73:2483-2492. https://doi. org/10.2527/1995.7382483x

- Hristov AN, Oh J, Firkins JL, Dijkstra J, Kebreab E, Waghorn G, Makkar HPS, Adesogan AT, Yang W, Lee W, Gerber PJ, Henderson B, Tricarico JM (2013). Mitigation of methane and nitrous oxide emissions from animal operations: I. A review of enteric methane mitigation options. J. Anim. Sci. 91: 5045-5069. https://doi.org/10.2527/jas.2013-6583

-Jouany JP, Morgavi DP (2007). Use of 'natural' products as alternatives to antibiotic feed additives in ruminant production. Animal. 1: 1443-166. https://doi.org/10.1017/ S1751731107000742

- Makkar HPS (2003). Effects and fate of tannins in ruminant animals, adaptation to tannins, and strategies to overcome detrimental effects of feeding tannin-rich feeds. Small Rum. Res. 49: 241-256. https://doi.org/10.1016/S09214488(03)00142-1

- Menke KH, Steingass H (1988). Estimation of the energetic feed value obtained from chemical analysis and gas production using rumen fluid. Anim. Res. Dev. 28:7-55.

- Ørskov ER, McDonald I (1979). The estimation of protein degradability in the rumen from incubation measurements weighted according to rate of passage. J. Agric. Sci. 92: 499503. https://doi.org/10.1017/S0021859600063048

-Patra AK, Kamra DN, Agarwal N (2010). Effects of extracts of spices on rumen methanogenesis, enzyme activities and fermentation of feeds in vitro. J. Sci. Food Agric. 90: 511520. https://doi.org/10.1002/jsfa.3849

-Santra A, Karim SA (2003). Rumen manipulation to improve 
animal productivity. Asian-Australas. J. Anim. Sci. 16: 748763. https://doi.org/10.5713/ajas.2003.748

-SAS (1998). User's Guide: Statistics, Version6, 12th Edition. SAS Inst. Inc., Cary, NC.

- Supapong C, Cherdthong A, Seankamsorn A, Khonkhaeng B, Wanapat M, Uriyapongson S, Gunun N, Gunun P, Chanjula P, Polyorach S (2017). In vitro fermentation, digestibility and methane production as influenced by Delonix regia seed meal containing tannins and saponins. J. Anim. Feed Sci. 26:123-130. https://doi.org/10.22358/jafs/73890/2017

-Tilley JMA, Terry RA (1963). A two-stage technique for the digestion of forage crops. J. Br. Grassl. Soc. 18: 104-111. https://doi.org/10.1111/j.1365-2494.1963.tb00335.x

- Van Soest PJ, Robertson JB, Lewis BA (1991). Methods for dietary fiber neutral detergent fiber, and nonstarch polysaccharides in relation to animal nutrition. J. Dairy Sci. 74: 3583-3597. https://doi.org/10.3168/jds.S00220302(91)78551-2

-Wang Z, Fang YZ (2004). Analysis of sugars in traditional Chinese drugs. J. Chromatogr. 812: 309-324. https://doi. org/10.1016/S1570-0232(04)00763-9 